\title{
Gaseous nitrogen losses from pig slurry fertilisation: can they be reduced with additives in a wheat crop?
}

\author{
Noemí Mateo-Marín, Ramón Isla and Dolores Quílez \\ Centro de Investigación y Tecnología Agroalimentaria de Aragón (CITA), Unidad de Suelos y Riegos (asociada a EEAD-CSIC). Avda. Montañana 930, \\ 50059 Zaragoza, Spain
}

\begin{abstract}
Aim of study: The use of pig slurry as fertiliser is associated with gaseous nitrogen $(\mathrm{N})$ losses, especially ammonia $\left(\mathrm{NH}_{3}\right)$ and nitrous oxide $\left(\mathrm{N}_{2} \mathrm{O}\right)$, leading to environmental problems and a reduction of its fertiliser value. This study evaluates, in an irrigated wheat crop, the effect of different additives mixed with pig slurry to decrease $\mathrm{NH}_{3}$ and $\mathrm{N}_{2} \mathrm{O}$ losses.

Area of study: Middle Ebro valley, Spain

Material and methods: The treatments were: i) non-N-fertilised control, ii) pig slurry (PS), iii) pig slurry with the urease inhibitor monocarbamide dihydrogen sulphate (PS-UI), iv) pig slurry with a microbial activator in development (PS-A), and v) pig slurry with the nitrification inhibitor 3,4-dimethylpyrazole phosphate (PS-NI). Pig slurry was applied at a target rate of $120 \mathrm{~kg} \mathrm{NH}_{4}{ }^{+}-\mathrm{N} \mathrm{ha}^{-1}$. Ammonia volatilisation was measured using semi-opened static chambers after treatments application at presowing 2016 and side-dressing 2017. Nitrous oxide emissions were measured using static closed chambers after treatments application at the 2017 and 2018 side-dressing.

Main results: Ammonia volatilisation was estimated to be $7-9 \%$ and $19-23 \%$ of $\mathrm{NH}_{4}{ }^{+}-\mathrm{N}$ applied after presowing and side-dressing applications, respectively. Additives were not able to reduce $\mathrm{NH}_{3}$ emissions in any application moment. PS-NI was the only treatment being effective in reducing $\mathrm{N}_{2} \mathrm{O}$ emissions, $70 \%$ respect to those in PS treatment. Crop yield parameters were not affected by the application of the additives because of the no effect of additives controlling $\mathrm{NH}_{3}$ losses and the low contribution of $\mathrm{N}_{2} \mathrm{O}$ losses to the $\mathrm{N}$ balance $(<1 \mathrm{~kg}$ $\mathrm{N}_{2} \mathrm{O}-\mathrm{N} \mathrm{ha}^{-1}$ ).
\end{abstract}

Research highlights: The use of 3,4-dimethylpyrazole phosphate would be recommended from an environmental perspective, although without grain yield benefits.

Additional key words: ammonia volatilisation; microbial activator; nitrification inhibitor; nitrous oxide emission; urease inhibitor.

Abbreviations used: DM (dry matter); DMPP (3,4-dimethylpyrazole phosphate); EF (emission factor); MCDHS (monocarbamide dihydrogen sulphate); NI (nitrification inhibitor); NUE (nitrogen use efficiency); PS (pig slurry); PS-A (pig slurry with a microbial activator in development); PS-NI (pig slurry with the nitrification inhibitor 3,4-dimethylpyrazole phosphate); PS-UI (pig slurry with the urease inhibitor monocarbamide dihydrogen sulphate); $\mathrm{RE}_{\mathrm{N}}$ (apparent $\mathrm{N}$ recovery efficiency); $\mathrm{SOC}$ (semi-opened free static chambers); UI (urease inhibitor).

Authors' contributions: Conception or design, obtaining funding and coordinating the research project: DQ. Acquisition and analysis of data, statistical analysis and drafting of the manuscript: NMM. Interpretation of data and critical revision of the manuscript for important intellectual content: NMM, RI, DQ. Supervising the work: RI, DQ.

Citation: Mateo-Marín, N; Isla, R; Quílez, D (2021). Gaseous nitrogen losses from pig slurry fertilisation: can they be reduced with additives in a wheat crop? Spanish Journal of Agricultural Research, Volume 19, Issue 3, e0302. https://doi.org/10.5424/sjar/2021193-17271

Supplementary material (Figs. S1, S2) accompanies the paper on SJAR's website

Received: 27 Jul 2020. Accepted: 09 Jun 2021.

Copyright (C) 2021 INIA. This is an open access article distributed under the terms of the Creative Commons Attribution 4.0 International (CC-by 4.0) License.

\begin{tabular}{|l|l|}
\hline Funding agencies/institutions & Project / Grant \\
\hline Instituto Nacional de Investigación y Tecnología Agraria y Alimentaria (INIA) & RTA2013-00057-C05-04 \\
& FPI-INIA CPD-2015-0044 \\
\hline Fondo de Inversión de Teruel (FITE 2016, Fondo Europeo de Desarrollo Regional) & \\
\hline
\end{tabular}

Competing interests: The authors have declared that no competing interests exist.

Correspondence should be addressed to Noemí Mateo-Marín: noemimateomarin@gmail.com

\section{Introduction}

Ammonia $\left(\mathrm{NH}_{3}\right)$ is an important atmospheric pollutant mostly emitted from agricultural sources. It leads to both environmental and socio-economic issues (EEA, 2019a).
Ammonia reacts with atmospheric nitric and sulphuric acids to form fine particulate matter $\left(\mathrm{PM}_{2.5}\right)$, considered a major environmental risk to human health (Hristov, 2011) since it is responsible for more than 410,000 premature deaths a year in Europe (EEA, 2019a). Besides, $\mathrm{NH}_{3}$ 
emission induces substantial environmental damages due to its effect on air pollution, soil acidification, water eutrophication, and loss of biodiversity (Vitousek et al., 1997; Ti et al., 2019).

Agriculture is responsible for the $92 \%$ of $\mathrm{NH}_{3}$ emissions in Europe (EEA, 2019a), 80\% of these emissions are attributable to livestock production systems and the remaining $20 \%$ is associated to synthetic fertilisers (EEA, 2016). In particular, spreading of manures and slurries for crop fertilisation causes $25 \%$ of these $\mathrm{NH}_{3}$ emissions (EEA, 2019b). In the EMEP/EEA air pollutant inventory guidebook (EEA, 2019c) the emission factor for the calculation of ammonia emissions for pig slurry application to soil (0.45) is much higher than for $\mathrm{N}$ fertiliser (average 0.05 ). North-eastern Spain is a hotspot of $\mathrm{NH}_{3}$ (Guevara et al., 2019) since this area gathers more than 15 million head of pigs (MAPA, 2020) comprising the $8 \%$ of total European pig livestock population (FAO, 2020).

The use of slurries as fertilisers could also imply nitrous oxide $\left(\mathrm{N}_{2} \mathrm{O}\right)$ emissions that might be influenced by the highly mineralised nature of the nitrogen $(\mathrm{N})$ contained in this product (Yagüe \& Quílez, 2012) in comparison to other organic fertilisers. Nitrous oxide is the largest ozone-depleting substance (UNEP, 2013) and the third most contributing emission to the greenhouse gas effect because of its atmospheric lifetime (121 years) and its radiative properties (GWP-100 yr. of 265) (Myhre et al., 2013). The metanalysis of Aguilera et al. (2013) shows that pig slurry has the same potential to produce $\mathrm{N}_{2} \mathrm{O}$ emissions than synthetic fertilisers and the 2019 refinement of the 2006 IPCC accounting methodology (IPCC, 2019) gives the same emission factor $(0.5 \%)$ for both fertiliser types.

Gaseous N losses associated with slurry management can be controlled through physical and chemical procedures. Ammonia volatilisation can be decreased, for example, using trail hoses for the slurry application instead of the splash plate (Yagüe et al., 2019), using slurries with low dry matter (DM) content (Bosch-Serra et al., 2014), and acidifying slurries (Fangueiro et al., 2015). Sanz-Cobena et al. (2017) compiled a set of practices applicable for the Mediterranean area to organic fertilisation to mitigate $\mathrm{N}_{2} \mathrm{O}$ emissions, some of them were also effective to reduce $\mathrm{NH}_{3}$ volatilisation as an indirect contributor to $\mathrm{N}_{2} \mathrm{O}$ emission. These practices include those devoted to decrease the contact surface between the fertiliser and the atmosphere (e.g. slurry injection into the soil or immediate incorporation of slurries into the soil after their application), adjusting $\mathrm{N}$ rates to actual crop uptake, and the use of inhibitors (nitrification inhibitors or urease inhibitors) as additives to fertilisers.

Nitrification inhibitors (NIs) are applied on ammonium-based fertilisers to delay the conversion of ammonium to nitrite by the depression of the Nitrosomonas activity (Zerulla et al., 2001a,b). Urease inhibitors (UIs) are considered for urea-based fertilisers since these subs- tances delay the conversion of urea to ammonium $\left(\mathrm{NH}_{4}^{+}\right)$ by the inhibition of the urease enzyme activity (Ussiri \& Lal, 2013).

3,4-dimethylpyrazole phosphate (DMPP), one of the most extensively used NI (Abalos et al., 2014), has been traditionally blended into mineral fertilisers. However, a novel formulation based on DMPP (Vizura ${ }^{\circledR}$ ) has been developed for liquid manure and biogas digestate. Monocarbamide dihydrogen sulphate (MCDHS; international patent WO 2007/132032 A1) is another substance marketed as urease inhibitor but there is no available information in the scientific literature to support its potential under field conditions. The manufacturing company also claims the protection of ammonium- $\mathrm{N}$ controlling $\mathrm{pH}$ levels and decreasing $\mathrm{NH}_{3}$ volatilisation due to the micro-acidification produced in the hydrolysis of the MCDHS molecule, releasing protons $\mathrm{H}^{+}$.

In this context, the objective of this study was to evaluate in a wheat crop and under Mediterranean irrigated conditions, the effectiveness of the UI MCDHS, a soil microbial activator (developed in the Spanish Ministry of Science and Innovation project CDTI IDI-20170513), and the NI Vizura ${ }^{\circledR}$ to abate ammonia volatilisation and nitrous oxide emissions from surface applied pig slurry.

\section{Material and methods}

\section{Site and experimental design}

The trial was conducted at the experimental field 'Soto Lezcano' (middle Ebro Valley, Spain) during two wheatgrowing seasons (2016/17 and 2017/18) under semiarid Mediterranean-continental irrigated conditions. The climate is characterised by mean annual air temperature of $14.6{ }^{\circ} \mathrm{C}$ and mean annual precipitation and reference evapotranspiration of $318 \mathrm{~mm}$ and 1,243 $\mathrm{mm}$, respectively (period 2004-2019). The trial was established on a deep $(>120 \mathrm{~cm})$ Typic Xerofluvent soil (Soil Survey Staff, 2014; Table 1) where bread wheat (Triticum aestivum L. cv. 'Rimbaud') was cultivated under sprinkler irrigation. Crop water needs were calculated weekly from the reference evapotranspiration (ETo) estimated with the Penman-Monteith equation and the locally adapted crop coefficients $(\mathrm{Kc})$ according to FAO procedures (Allen et al., 1998). Thereby, the crop received a total of $435 \mathrm{~mm}$ and $428 \mathrm{~mm}$ of water (rain plus irrigation) to supply the estimated crop ET of $429 \mathrm{~mm}$ and $383 \mathrm{~mm}$, respectively, during the two cropping seasons.

The experiment had a randomised block design with four replicates and four treatments with a plot size of 2.0 $\times 3.6 \mathrm{~m}$. The experiment was replicated three times: presowing 2016, side-dressing 2017 (both in the same crop cycle), and side-dressing 2018. Slurry from fattening pigs was used in the three trials (Table 2) and the four evaluated 
Table 1. Physicochemical characteristics of the soil at the beginning of the experiment.

\begin{tabular}{lcc}
\hline & $\mathbf{0 - 3 0} \mathbf{~ c m}$ & $\mathbf{3 0 - 6 0} \mathbf{~ c m}$ \\
\hline Soil texture & silt loam & silt loam \\
Sand $(\%)$ & 32.5 & 31.1 \\
Silt $(\%)$ & 50.5 & 51.9 \\
Clay (\%) & 17.0 & 17.0 \\
Stoniness $(\%$ vol $)$ & 1 & 1 \\
Total nitrogen $(\mathrm{Kjeldahl})\left(\mathrm{mg} \mathrm{kg}^{-1}\right)$ & 1,350 & 940 \\
Phosphorous $(\mathrm{Olsen})\left(\mathrm{mg} \mathrm{kg}^{-1}\right)$ & 43 & 12.1 \\
Potassium $\left(\mathrm{NH}_{4} \mathrm{Ac}\right)\left(\mathrm{mg} \mathrm{kg}^{-1}\right)$ & 408 & 231 \\
Organic matter $(\%)$ & 1.84 & 0.92 \\
pH $\left(1: 2.5_{\mathrm{H} 2 \mathrm{O}}\right)$ & 8.36 & 8.36 \\
Electrical conductivity $\left(1: 5_{\mathrm{H} 2 \mathrm{O}}\right)\left(\mathrm{dS} \mathrm{m}{ }^{-1}\right)$ & 0.265 & 0.261 \\
\hline
\end{tabular}

additives were provided by the manufacturing companies. The slurry was applied by hand to the experimental plots at a target rate of $120 \mathrm{~kg} \mathrm{NH}_{4}{ }^{+}-\mathrm{N} \mathrm{ha}^{-1}$ in all treatments (actual rates in Table 2). Nitrogen fertiliser treatments were: a) non-N application (Control); b) pig slurry (PS); c) pig slurry mixed with the urease inhibitor monocarbamide dihydrogen sulphate (PS-UI); d) pig slurry mixed with a soil microbial activator (PS-A) or with nitrification inhibitor 3,4-dimethylpyrazole phosphate (Vizura ${ }^{\circledR}$; PSNI). At side-dressing application in 2018, the PS-A was substituted by the PS-NI treatment. The urease inhibitor MCDHS was included as PS slurry additive treatment to assess the micro-acidification effect on ammonia losses declared by the manufacturing company that patented the inhibitor. The additives were applied according to the rate recommended by the manufacturing company: $2.5 \mathrm{~L}$ of
MCDHS in $1 \mathrm{Mg}$ of pig slurry, $2.5 \mathrm{~kg}$ of soil microbial activator in $1 \mathrm{Mg}$ of pig slurry, and $3 \mathrm{~L}$ of Vizura ${ }^{\circledR}$ per hectare. Pig slurry was applied at presowing $\left(14^{\text {th }}\right.$ November 2016) and at side-dress at tillering $\left(7^{\text {th }}\right.$ April 2017 and $19^{\text {th }}$ March 2018). At presowing in the two cropping seasons, $70 \mathrm{~kg} \mathrm{P}_{2} \mathrm{O}_{5} \mathrm{ha}^{-1}$ and $150 \mathrm{~kg} \mathrm{~K}_{2} \mathrm{O} \mathrm{ha}^{-1}$ were applied to avoid limitations of these two nutrients.

The crop was managed according to standard practices in the region. Wheat was sown on $30^{\text {th }}$ December 2016 and $16^{\text {th }}$ November 2017 at a plant density of 200 and $175 \mathrm{~kg}$ seed ha ${ }^{-1}$, respectively. The crop was harvested at wheat maturity ( $4^{\text {th }}$ July 2017 and $6^{\text {th }}$ July 2018). Straw was hashed and incorporated to the soil before subsequent wheat seeding. Weeds, diseases, and pests were controlled and no special problems were detected during the experimental period.

Table 2. Physicochemical characteristics of the pig slurry and amount of nitrogen applied at presowing 2016, side-dressing 2017, and side-dressing 2018.

\begin{tabular}{|c|c|c|c|}
\hline & \multicolumn{2}{|c|}{ 2016/17 } & \multirow{2}{*}{$\begin{array}{c}2017 / 18 \\
\text { Side-dressing } \\
2018\end{array}$} \\
\hline & $\begin{array}{c}\text { Presowing } \\
2016\end{array}$ & $\begin{array}{c}\text { Side-dressing } \\
2017\end{array}$ & \\
\hline Density $\left(\mathrm{kg} \mathrm{m}^{-3}\right)$ & 1,030 & 1,034 & 1,022 \\
\hline $\mathrm{pH}$ & - & 7.6 & 7.8 \\
\hline Electrical conductivity at $25^{\circ} \mathrm{C}\left(\mathrm{dS} \mathrm{m}^{-1}\right)$ & 30.6 & 30.2 & 35.4 \\
\hline Dry matter $\left(\mathrm{kg} \mathrm{DM} \mathrm{m}^{-3}\right)$ & 41.4 & 73.4 & 31.6 \\
\hline Organic matter $\left(\mathrm{kg} \mathrm{OM} \mathrm{m}^{-3}\right)$ & 26.1 & 53.7 & 17.1 \\
\hline Ammonium nitrogen $\left(\mathrm{kg} \mathrm{N} \mathrm{m}^{-3}\right)$ & 3.2 & 4.5 & 4.0 \\
\hline Organic nitrogen $\left(\mathrm{kg} \mathrm{N} \mathrm{m}^{-3}\right)$ & 0.3 & 0.9 & 0.9 \\
\hline Phosphorous $\left(\mathrm{kg} \mathrm{P}_{2} \mathrm{O}_{5} \mathrm{~m}^{-3}\right)$ & 0.6 & 0.3 & 0.6 \\
\hline Potassium $\left(\mathrm{kg} \mathrm{K}_{2} \mathrm{O} \mathrm{m}^{-3}\right)$ & 4.0 & 4.3 & 4.5 \\
\hline Ammonium-N $\left(\mathrm{kg} \mathrm{NH}_{4}{ }^{+}-\mathrm{N} \mathrm{ha}^{-1}\right)$ & 141 & 157 & 158 \\
\hline Total-N (kg N ha-1) & 155 & 208 & 191 \\
\hline
\end{tabular}




\section{Ammonia volatilisation}

Ammonia volatilisation was measured at presowing 2016 and side-dressing 2017 using semi-opened free static chambers (SOC), similar to those of Araújo et al. (2009). Two polyethylene terephthalate chambers per plot (31.0-cm height and 10.3-cm inner diameter, $2-\mathrm{L}$ volume bottle with the bottom cut) were located $2 \mathrm{~cm}$ above the soil surface and with a $2-\mathrm{cm}$ diameter upper hole that ensured airflow. The removed bottom was situated $2 \mathrm{~cm}$ above the upper hole to avoid the entrance of rain and irrigation water into the chamber. Inside the chamber, there was an absorbent Spontex ${ }^{\circledR}$ Origin foam strip (Mapa Spontex Ibérica SA, Sant Cugat del Vallès, Spain) of $25.0 \times 2.5 \times 0.5 \mathrm{~cm}($ length $\times$ wide $\times$ thickness) and $0.087 \mathrm{~g} \mathrm{~cm}^{-3}$ (density) previously impregnated in acid solution $\left(60 \mathrm{~mL} \mathrm{H}_{2} \mathrm{SO}_{4}, 1 \mathrm{~mol}\right.$ $\mathrm{dm}^{-3}+$ glycerine $\left.(2 \% \mathrm{v} / \mathrm{v})\right)$. The bottom end of the strip was immersed in a $100-\mathrm{mL}$ plastic jar with $50 \mathrm{~mL}$ of the acid solution in permanent contact with the strip. The trapped ammonia in the foam strip was extracted with $250 \mathrm{~mL}$ of $2 \mathrm{M} \mathrm{KCl}$. The extracts were analysed to determine ammonium concentration by colourimetry using a segmented flow analyser (AutoAnalyser 3, Bran+Luebbe, Germany).

Samplings started the day of slurry application, foam strips were changed with a frequency ranging from twice a day during the first two days to once a week during the last weeks. Samplings were performed until 28 days after presowing fertilisation in 2016 (11 samplings) and 14 days after side-dressing fertilisation in 2017 (10 samplings) since spring weather conditions and irrigation management promoted that ammonia volatilisation stooped in a shorter timespan than in autumn. Ammonia volatilisation was not measured after side-dressing application in 2018.

Semi-open chambers are not able to measure absolute $\mathrm{NH}_{3}$ emissions as the acid strips are not able to trap all the $\mathrm{NH}_{3}$ emitted from the soil, so they need to be calibrated determining their efficiency trapping ammonia. Thus, the efficiency of the SOC trapping ammonia was determined in the laboratory using three solutions with known concentrations of ammonium (407 $\mathrm{mg} \mathrm{NH}_{4}^{+}-\mathrm{N}$ $\mathrm{L}^{-1}, 289 \mathrm{mg} \mathrm{NH}_{4}^{+}-\mathrm{N} \mathrm{L}^{-1}$, and $\left.237 \mathrm{mg} \mathrm{NH}_{4}^{+}-\mathrm{N} \mathrm{L}^{-1}\right)$. SOCs were placed (by triplicate) over 100-mm diameter Petri dishes containing $30 \mathrm{~mL}$ of each of the three solutions. After 24 hours, the $\mathrm{NH}_{4}{ }^{+}-\mathrm{N}$ trapped by foam strips and the volume and $\mathrm{NH}_{4}{ }^{+}-\mathrm{N}$ concentration of the remaining solutions were quantified. SOC efficiency was defined as the ratio between $\mathrm{NH}_{4}{ }^{+} \mathrm{N}$ trapped by the foam and the volatilised $\mathrm{NH}_{3}$ estimated as the difference between the initial amount of ammonium in the Petri dish and the remaining amount after 24 hours. Efficiency in the field could not be determined because the solution with the known concentration was systematically polluted.
Ammonia captured in the control treatment was subtracted from the ammonia captured at each PS treatment and then divided by the efficiency to obtain the amount of ammonia volatilised in the PS treatments.

\section{Direct nitrous oxide emissions}

Directnitrous oxide emissions were measured in side-dressing 2017 and 2018 using a manual closed chamber methodology. The closed-chamber technique and the $\mathrm{N}_{2} \mathrm{O}$ flux measurement procedure were similar to those described by Mateo-Marín et al. (2020). Shortly, polyvinyl chloride upper cover of chambers (18.5-cm height and 30.0-cm inner diameter) wrapped in reflective insulation film were set on collars inserted $10 \mathrm{~cm}$ into the soil, creating 13.1-L chamber headspace. At each sampling, $15 \mathrm{~mL}$ of inner air were taken using a polypropylene syringe at 0 and $60 \mathrm{~min}$ after chamber closure. The samples were injected into 12-mL Exetainer borosilicate glass vials (Model 038W, Labco). Samplings started roughly at the hour with the mean temperature of the day (between 9:30h and 11:00h GMT; Alves et al., 2012). Samples were analysed by gas chromatography using an Agilent 7890B gas chromatography system with HP-Plot Q column and electron-capture, flame-ionisation and methaniser detectors.

Direct nitrous oxide emission rates were calculated as the linear increment in gas concentration (corrected for the air temperature) in the chamber headspace and multiplied by the ratio between the chamber volume and the soil area covered by the chamber (MacKenzie et al., 1998).

In both seasons, nitrous oxide measurements started just before the pig slurry application at tillering and ended at harvest. The samplings had daily frequency after fertilisation (during six days) and then measurements were spreading from once a week to once every two weeks, with a total of 12 and 17 sampling dates in 2017 and 2018, respectively.

The $\mathrm{N}_{2} \mathrm{O}$ emission factor (EF, \%) was calculated as the ratio between the difference of cumulative $\mathrm{N}_{2} \mathrm{O}$ emissions in fertilised and unfertilised $\mathrm{N}$ plots, and the amount of the $\mathrm{N}$ applied in the fertilised plots and multiplied by 100 . The yield-scaled $\mathrm{N}_{2} \mathrm{O}$ emission ( $\mathrm{YS}_{\mathrm{N} 2 \mathrm{O}} ; \mathrm{g} \mathrm{N} \mathrm{kg}^{-1}$ grain) is the ratio between the cumulative $\mathrm{N}_{2} \mathrm{O}$ emissions and the grain yield.

\section{Soil mineral nitrogen}

Soil (0-15 cm and 15-30 cm depths) was sampled in the three experimental periods (presowing 2016, side-dressing 2017 and side-dressing 2018) with daily frequency the first 5 days after fertilisation and decreasing the frequency later to reach once a week at the end of the sampling period (total of 11,12 , and 15 sampling dates in presowing 2016, side-dressing 2017, and 
side-dressing 2018, respectively). Two soil core samples were taken per plot to make a composite sample for each depth. Samples were sieved $(3 \mathrm{~mm})$ and two subsamples were obtained. A subsample was dried at $105{ }^{\circ} \mathrm{C}$ until constant weight to determine gravimetric soil water content. Another subsample of $10 \mathrm{~g}$ of fresh soil was extracted with $30 \mathrm{~mL}$ of $2 \mathrm{~N} \mathrm{KCl}$, shaken for $30 \mathrm{~min}$, and filtered through cellulose filter. Nitrate $\left(\mathrm{NO}_{3}{ }^{-}\right)$and ammonium concentration in extracts were analysed by colourimetry using a segmented flow analyser (AutoAnalyser 3, Bran+Luebbe, Germany).

\section{Productive parameters and efficiency in the use of nitrogen}

At wheat maturity, each plot was hand-harvested in two random areas of $0.54 \mathrm{~m}^{2}$ to obtain the grain (adjusted to $120 \mathrm{~g} \mathrm{~kg}^{-1}$ ) and aboveground biomass yield. Subsamples of grain and straw were dried at $65^{\circ} \mathrm{C}$ and milled to obtain the grain and straw $\mathrm{N}$ concentration by dry combustion (TruSpec CN, LECO, St. Joseph, MI, USA).

Two parameters were used to compare the efficiency in the use of $\mathrm{N}$ between treatments, the nitrogen use efficiency (NUE) and the apparent $\mathrm{N}$ recovery efficiency $\left(\mathrm{RE}_{\mathrm{N}}\right)$. NUE is the relation between the total aboveground $\mathrm{N}$ uptake and the $\mathrm{N}$ applied by fertilisation. $\mathrm{RE}_{\mathrm{N}}$ is the increment in the aboveground $\mathrm{N}$ uptake due to the $\mathrm{N}$ application per unit of $\mathrm{N}$ applied (Eq. 1):

$$
\mathrm{RE}_{\mathrm{N}}=\frac{\mathrm{U}_{\mathrm{T}}-\mathrm{U}_{0}}{\mathrm{~F}_{\mathrm{T}}}
$$

where $U_{T}$ is the $\mathrm{N}$ uptake by aboveground biomass in the $T$ treatment; $U_{0}$ is the $\mathrm{N}$ uptake by aboveground biomass in the unfertilised control plot; and $F_{T}$ is the amount of N applied in the $\mathrm{T}$ treatment. The mineral $\mathrm{N}$ contained in the applied slurry (i.e., $\left.\mathrm{NH}_{4}{ }^{+} \mathrm{N}\right)$ was used for the calculations since it was considered that the contribution of pig slurry organic $\mathrm{N}$ and its residual effect was not substantial during the period of the experiment.

\section{Statistical analysis}

Statistical analyses were performed using SAS $^{\circledR}$ software (University Edition, SAS Institute Inc., Cary, NC, USA). Normal distribution and homogeneity of variance were checked by Shapiro-Wilk and Levene's test, respectively, and variables were transformed when necessary (Box-cox transformation). Analysis of variance (MIXED procedure) was used to assess the existence of treatment effects and differences in treatment means were established with the Tukey's test at the 0.05 significance level. In cases with measurements over time (ammonia volatilisation, nitrous oxide emission, and soil mineral nitrogen content), repeated measure analysis was used according to a first-order autoregressive structure model AR(1).

\section{Results}

\section{Ammonia volatilisation}

In the study of efficiency, the amount of ammonia volatilised ranged between 8.9 and $15.4 \mathrm{~kg} \mathrm{~N} \mathrm{ha}^{-1}$ in the $24-$ hour period. The efficiency of the semi-opened chambers did not differ significantly among the three ammonium concentrations (Table 3). Mean efficiency was $24.6 \% \pm$ $0.7 \%$ (mean $\pm \mathrm{SE}$ ).

There were substantial differences in the environmental conditions between the two measurement periods (Fig. S1 [suppl]). Thus, the average temperature and wind speed during the experimental period were $7.2^{\circ} \mathrm{C}$ and 1.1 $\mathrm{m} \mathrm{s}^{-1}$ after presowing 2016 , and $15{ }^{\circ} \mathrm{C}$ and $2.0 \mathrm{~m} \mathrm{~s}^{-1}$ after side-dressing 2017.

The highest $\mathrm{NH}_{3}$ peak was trapped at 4.5-6.5 h after pig slurry application (Fig. 1). Ammonia trapped in fertilised treatments (mean $\pm \mathrm{SE}$ ) were $2.40 \pm 0.21 \mathrm{~g} \mathrm{~N}$ ha $^{-1}$ $\mathrm{min}^{-1}$ (presowing 2016) and $7.24 \pm 0.43 \mathrm{~g} \mathrm{~N} \mathrm{ha}^{-1} \mathrm{~min}^{-1}$ (side-dressing 2017). At the following sampling (23-24 h after pig slurry application), $\mathrm{NH}_{3}$ decreased to increase at the third sampling (27-31 $\mathrm{h}$ after pig slurry application) and decrease afterwards. A small emission peak was

Table 3. Efficiency of semi-open free static chambers absorbing ammonia volatilised from $30 \mathrm{~mL}$ aqueous solution (mean \pm standard deviation) of three different ammonium concentrations $\left(\mathrm{C} 1=407, \mathrm{C} 2=289\right.$, and $\left.\mathrm{C} 3=237 \mathrm{~kg} \mathrm{NH}_{4}{ }^{+}-\mathrm{N} \mathrm{ha}^{-1}\right)$ during a period of one day. Initial and final amounts of ammonium in the solutions, and amount of ammonium absorbed by the semi-open free static chambers.

\begin{tabular}{lccc}
\hline & $\mathbf{C 1}$ & $\mathbf{C 2}$ & $\mathbf{C 3}$ \\
\hline Initial $\left(\mathrm{kg} \mathrm{NH}_{4}^{+}-\mathrm{N} \mathrm{ha}^{-1}\right)$ & 15.5 & 11.1 & 9.1 \\
Final $\left(\mathrm{kg} \mathrm{NH}_{4}^{+}-\mathrm{N} \mathrm{ha}^{-1}\right)$ & $0.113( \pm 0.001)$ & $0.088( \pm 0.004)$ & $0.076( \pm 0.001)$ \\
Absorbed $\left(\mathrm{kg} \mathrm{NH}_{4}{ }^{-} \mathrm{N} \mathrm{ha}^{-1}\right)$ & $4.01( \pm 0.23)$ & $2.67( \pm 0.05)$ & $2.11( \pm 0.11)$ \\
Efficiency $(\%)^{[a]}$ & $26.0 \%( \pm 1.5 \%)$ & $24.4 \%( \pm 0.4 \%)$ & $23.5 \%( \pm 1.3 \%)$ \\
\hline
\end{tabular}

${ }^{[a]}$ Efficiency did not differ significantly between the three concentrations (Tukey's test, $p>0.05$ ). 

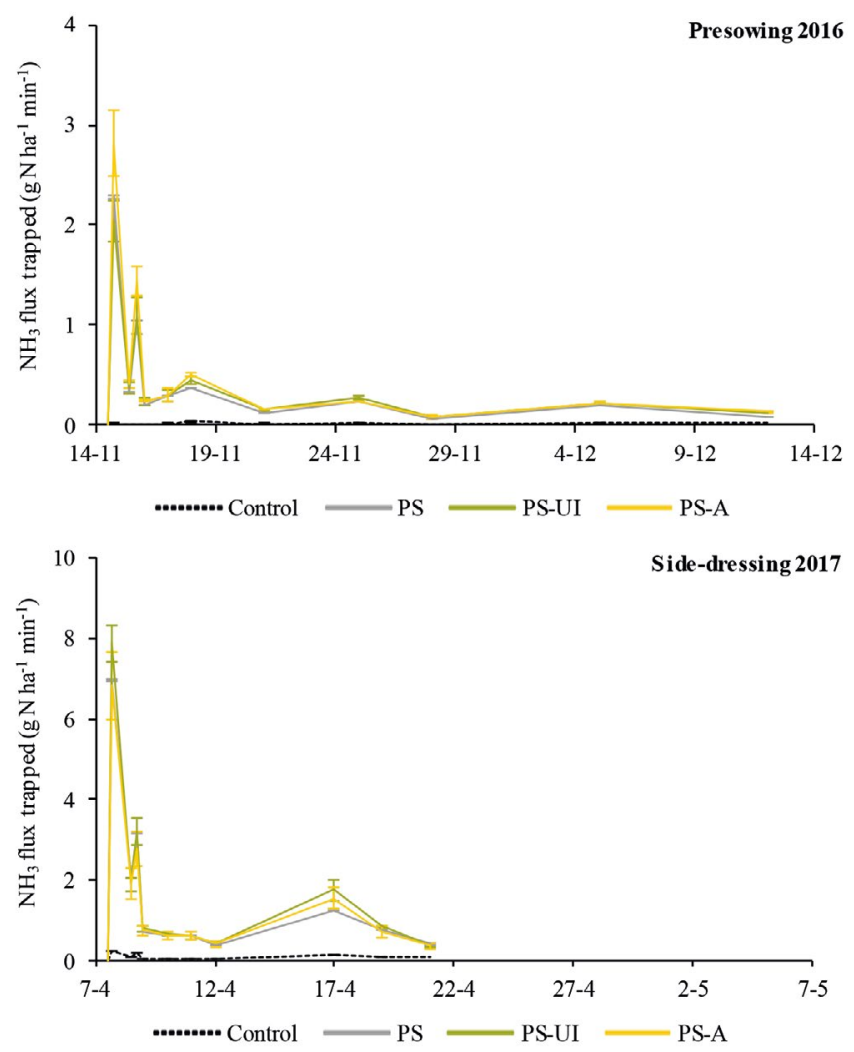

Figure 1. Temporal changes of average ammonia fluxes ( $\mathrm{g} \mathrm{N}$ $\left.\mathrm{ha}^{-1} \mathrm{~min}^{-1}\right)$ trapped by the semi-opened free static chamber for each treatment (Control, PS: pig slurry, PS-UI: pig slurry + MCDHS, and PS-A: pig slurry + microbial activator) at presowing 2016 and side-dressing 2017. Year data: day-month. Vertical bars indicate standard error $(n=4)$.

trapped 10 days after the slurry application in side-dressing 2017. This peak is thought to be related to the degradation of the foam strips during the 5-day exposition period between $12^{\text {th }}$ and $17^{\text {th }}$ April.

No significant differences (repeated measure analysis) in $\mathrm{NH}_{3}$ fluxes among the three pig slurry treatments were observed; however, all three treatments presented significantly higher fluxes than the non-fertilised control. The $\mathrm{NH}_{3}$ fluxes were $280 \%$ and $479 \%$ higher in the fertilised treatments than in the Control for presowing 2016 and side-dressing 2017, respectively.

Cumulative ammonia volatilised after three, fourteen, and twenty-eight days after treatments application are presented in Table 4. During the first three days, $\mathrm{NH}_{3}$ losses reached more than $50 \%$ of the total $\mathrm{NH}_{3}$ emitted during the whole measurement period (51\% for presowing 2016 and $65 \%$ for side-dressing 2017) and fourteen days after fertilisation, $\mathrm{NH}_{3}$ losses represented $91 \%$ of the total measured losses of the period. No differences $(p>0.05)$ were found in the cumulative $\mathrm{NH}_{3}$ emissions among fertiliser treatments for any period $(3,14$, or 28 days, whatever it was the application moment, presowing or side-dress). Ammonia volatilisation losses in the period of fourteen days after pig slurry application were, on average, 34\% larger $(p<0.0001)$ during side-dress than during presowing application.

\section{Direct nitrous oxide emission}

Soil temperature and water filled pore space (WFPS) at 10-cm depth during the $\mathrm{N}_{2} \mathrm{O}$ samplings are shown in Fig. S2 [suppl]. Mean $\mathrm{N}_{2} \mathrm{O}$ fluxes ranged from $-0.5 \mathrm{~g}$ $\mathrm{N} \mathrm{ha}^{-1}$ day $^{-1}$ to $66.9 \mathrm{~g} \mathrm{~N} \mathrm{ha}^{-1}$ day $^{-1}$ for both cropping seasons (Fig. 2). Significant differences were observed between treatments: Control showed lower $\mathrm{N}_{2} \mathrm{O}$ fluxes in comparison to the fertilised treatments in side-dressing 2017, and Control and PS-NI showed lower $\mathrm{N}_{2} \mathrm{O}$ fluxes than PS and PS-A in side-dressing 2018 (repeated measure analysis; $p<0.05$ ). The same behaviour was found in cumulative $\mathrm{N}_{2} \mathrm{O}$ emissions. The $\mathrm{N}_{2} \mathrm{O}$ emissions were on average 2.8 times higher in the PS treatments than in the non-fertilised control. However, in side-dressing 2018, the PS-NI

Table 4. Average cumulative ammonia volatilised ${ }^{[a]}\left(\mathrm{kg} \mathrm{N} \mathrm{ha}^{-1} ; \mathrm{n}=4\right)$ and percentage respect to ammonium nitrogen applied with the pig slurry in the different treatments (PS: pig slurry, PSUI: pig slurry + MCDHS, and PS-A: pig slurry + microbial activator). The results are presented separately by application moment (presowing 2016 and side-dress 2017) at three timespans (3, 14 , and 28 days) after application.

\begin{tabular}{lccccc}
\hline & PS & PS-UI & PS-A & DF & $p$-value \\
\hline Presowing 2016 & & & & & \\
$\quad 3$ days & $5.4(3.8 \%)$ & $5.3(3.8 \%)$ & $6.6(4.6 \%)$ & 6 & 0.197 \\
14 days & $9.0(6.4 \%)$ & $9.6(6.8 \%)$ & $11.2(7.9 \%)$ & 6 & 0.181 \\
28 days & $9.7(6.9 \%)$ & $10.5(7.4 \%)$ & $12.1(8.6 \%)$ & 6 & 0.158 \\
Side-dressing 2017 & & & & & \\
3 days & $17.9(13.0 \%)$ & $19.0(13.8 \%)$ & $20.8(15.2 \%)$ & 6 & 0.695 \\
14 days & $26.4(19.3 \%)$ & $28.9(21.1 \%)$ & $31.6(23.0 \%)$ & 6 & 0.609 \\
\hline
\end{tabular}

[a] Considering $24.6 \%$ as the efficiency of the method to trap the ammonia volatilised and discounting the amount of ammonia trapped in the control (background) treatment. 

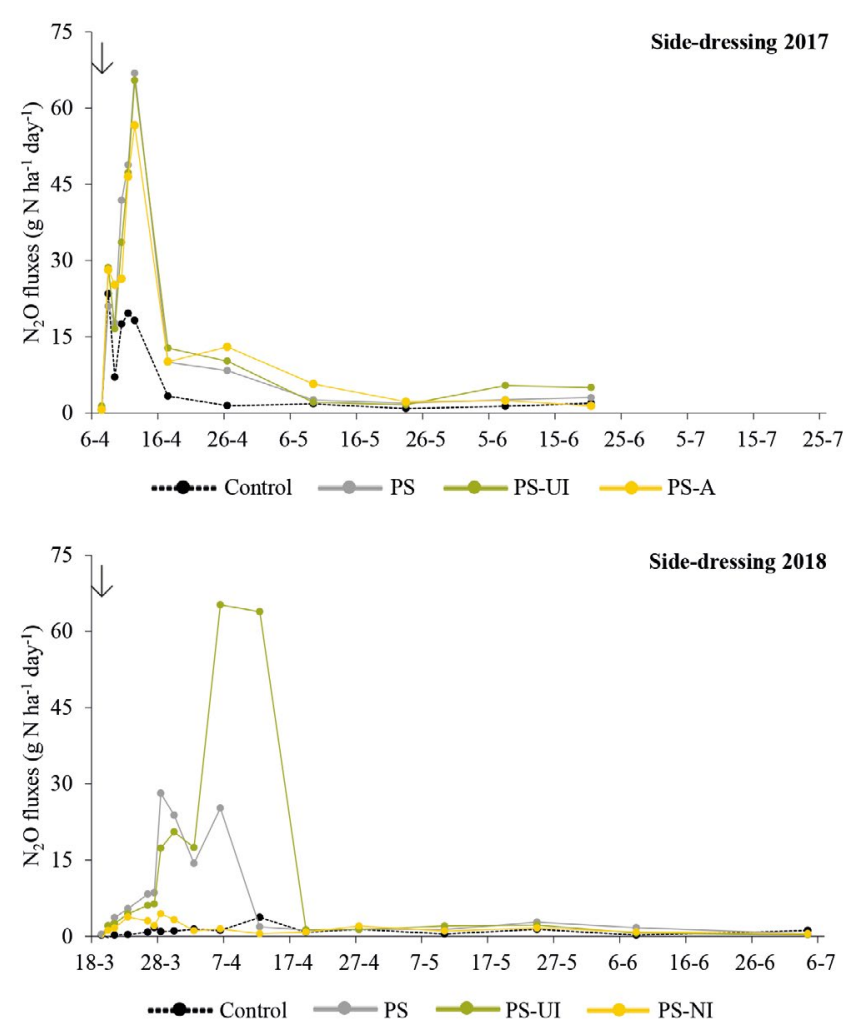

Figure 2. Temporal $\mathrm{N}_{2} \mathrm{O}$ fluxes $\left(\mathrm{g} \mathrm{N} \mathrm{ha}^{-1}\right.$ day $\left.^{-1}\right)$ for each treatment (Control, PS: pig slurry, PS-UI; pig slurry + MCDHS, PSA: pig slurry + microbial activator, PS-NI: pig slurry + Vizura $^{\circledR}$ ) after pig slurry application (tillering) at side-dressing 2017 and side-dressing 2018. Year data: day-month. Arrows indicate fertilisation day.

treatment decreased the $\mathrm{N}_{2} \mathrm{O}$ emissions at the same level that the Control, with lower emissions than the PS and PSUI treatments $(p<0.05)$. Although a large $\mathrm{N}_{2} \mathrm{O}$ emission was observed in the PS-UI $\left(1,014 \mathrm{~g} \mathrm{~N}^{-1}\right)$ during side-dressing 2018 , it was not significantly different from that in the PS.
Crop season EFs for direct $\mathrm{N}_{2} \mathrm{O}$ and $\mathrm{YS}_{\mathrm{N} 2 \mathrm{O}}$ emissions did not show differences between treatments in side-dressing 2017, but in side-dressing 2018, the treatment with NI presented the lowest values (Table 5) for both variables. EFs were $92 \%$ and $97 \%$ significantly lower in PS-NI than in PS and PS-UI, respectively; and $\mathrm{YS}_{\mathrm{N} 2 \mathrm{O}}$ were $71 \%$ and $87 \%$ significantly lower in PS-NI than in PS and PSUI, respectively.

\section{Soil mineral nitrogen}

After presowing application of PS, soil mineral $\mathrm{N}$ concentration was affected by treatments only in the top layer (0-15 cm in Table 6; 15-30 cm not shown). Differences were only significant between PS-UI and PS-A, and no effects of the additives mixed with the PS were detected. However, these differences were not noticed in the side-dress application (2017) whatever it was the considered depth $(0-15 \mathrm{~cm}$ or $15-30 \mathrm{~cm})$. During the next season (side-dressing 2018), soil nitrate concentration $(0-15 \mathrm{~cm})$ in PS-NI was $32 \%$ and $28 \%$ lower than in PS and PS-UI $(p<0.05)$, respectively; and soil ammonium concentration $(0-15 \mathrm{~cm})$ in PS-NI was $32 \%$ and $23 \%$ higher than in PS and PS-UI, respectively, but not significantly. The opposite behaviour of soil nitrate and ammonium concentrations generated no differences $(p>0.05)$ among treatments in soil mineral $\mathrm{N}$ content.

\section{Productive parameters and efficiency in the use of nitrogen}

Table 7 shows that no differences in grain yield $(p>0.05)$ were found among treatments for any of the

Table 5. Average $(\mathrm{n}=4)$ cumulative direct nitrous oxide emissions $\left(\mathrm{g} \mathrm{N} \mathrm{ha}^{-1}\right)$, crop season emission factor $(\%)$, and yield-scaled $\mathrm{N}_{2} \mathrm{O}$ emission $\left(\mathrm{g} \mathrm{N} \mathrm{kg}^{-1}\right.$ grain) in the different fertiliser treatments. The results are presented separately by growing seasons with fertiliser application at side-dress (2016/17 and 2017/18). Values followed by the same letter were not significantly different ( $p>0.05$, Tukey's test).

\begin{tabular}{llccccc}
\hline & Control & PS & PS-UI & PS-A & DF & $\boldsymbol{p}$-value \\
\hline Side-dressing 2017 & & & & & & \\
$\mathrm{N}_{2} \mathrm{O}$ emission $\left(\mathrm{g} \mathrm{N} \mathrm{ha}^{-1}\right)$ & $229.9 \mathrm{~b}$ & $610.6 \mathrm{a}$ & $685.3 \mathrm{a}$ & $661.5 \mathrm{a}$ & 9 & $<0.001$ \\
$\mathrm{Crop} \mathrm{season} \mathrm{EF}(\%)$ & - & 0.19 & 0.22 & 0.21 & 6 & 0.483 \\
YSN2O $\left(\mathrm{g} \mathrm{N} \mathrm{kg}^{-1}\right.$ grain) & - & 0.11 & 0.13 & 0.13 & 6 & 0.312 \\
\hline & Control & PS & PS-UI & PS-NI & DF & $\boldsymbol{p}$-value \\
\hline Side-dressing 2018 & & & & & & \\
$\mathrm{N}_{2} \mathrm{O}$ emission $\left(\mathrm{g} \mathrm{N} \mathrm{ha}^{-1}\right)$ & $111.8 \mathrm{~b}$ & $460.9 \mathrm{a}$ & $1014.4 \mathrm{a}$ & $139.5 \mathrm{~b}$ & 9 & $<0.001$ \\
$\mathrm{Crop} \mathrm{season} \mathrm{EF}(\%)$ & - & $0.24 \mathrm{ab}^{[\mathrm{a}]}$ & $0.60 \mathrm{a}$ & $0.02 \mathrm{~b}^{[\mathrm{x}]}$ & 6 & 0.033 \\
YSN2O $\left(\mathrm{g} \mathrm{N} \mathrm{kg}^{-1}\right.$ grain) & - & $0.07 \mathrm{a}$ & $0.15 \mathrm{a}$ & $0.02 \mathrm{~b}$ & 6 & 0.001 \\
\hline
\end{tabular}

${ }^{[\mathrm{x}]}$ Differences were found when just the two treatments were analysed using Tukey's test. This comparison was performed since the huge values of $\mathrm{N}_{2} \mathrm{O}$ emissions in PS-UI hid differences. EF: emission factor. $\mathrm{YS}_{\mathrm{N} 2 \mathrm{O}}$ : yield-scaled $\mathrm{N}_{2} \mathrm{O}$ emission 
Table 6. Average $(\mathrm{n}=4)$ nitrate $\left(\mathrm{NO}_{3}^{-}, \mathrm{mg} \mathrm{N} \mathrm{kg}{ }^{-1}\right.$ soil), ammonium $\left(\mathrm{NH}_{4}^{+}-, \mathrm{mg} \mathrm{N} \mathrm{kg}^{-1}\right.$ soil) and mineral $\mathrm{N}$ ( $\mathrm{Nmin}$; $\mathrm{mg} \mathrm{N} \mathrm{kg}{ }^{-1}$ soil) concentration from 0 to $15-\mathrm{cm}^{-}$depth in the one month after PS application in the fertiliser treatments (PS: pig slurry, PS-UI: pig slurry + MCDHS, PS-A: pig slurry + microbial activator, and PS-NI: pig slurry + DMPP). The results are presented separately by periods (presowing 2016, side-dressing 2017, and side-dressing 2018). Values followed by the same letter were not significantly different ( $p>0.05$, Tukey's test).

\begin{tabular}{lccccccc}
\hline & PS & PS-UI & PS-A & DF & $\mathbf{T}^{[1]}$ & $\mathbf{S}^{[1,2]}$ & $\mathbf{T} \times \mathbf{S}^{[1]}$ \\
\hline Presowing 2016 & & & & & & & \\
$\mathrm{NO}_{3}{ }^{-}$ & $15.5 \mathrm{ab}$ & $12.6 \mathrm{~b}$ & $18.2 \mathrm{a}$ & 72 & $<0.001$ & $<0.001$ & 1.000 \\
$\mathrm{NH}_{4}{ }^{+}$ & 35.1 & 34.1 & 41.0 & 72 & 0.654 & $<0.001$ & 0.534 \\
$\mathrm{Nmin}$ & $50.6 \mathrm{ab}$ & $46.8 \mathrm{~b}$ & $59.2 \mathrm{a}$ & 72 & 0.001 & $<0.001$ & 0.628 \\
Side-dressing 2017 & & & & & & & \\
$\mathrm{NO}_{3}^{-}$ & 11.1 & 11.8 & 14.8 & 72 & 0.053 & $<0.001$ & 0.131 \\
$\mathrm{NH}_{4}{ }^{-}$ & 2.0 & 2.7 & 2.0 & 72 & 0.276 & $<0.001$ & 0.646 \\
$\mathrm{Nmin}^{-13.1}$ & 14.5 & 16.8 & 72 & 0.124 & $<0.001$ & 0.093 \\
\hline $\mathbf{S i d e}^{-d r e s s i n g ~ 2018}$ & PS & PS-UI & PS-NI & $\mathbf{D F}$ & $\mathbf{T}^{[1]}$ & $\mathbf{S}$ & $\mathbf{T} \times \mathbf{S}^{[1]}$ \\
$\mathrm{NO}_{3}^{-}$ & $8.4 \mathrm{a}$ & $7.9 \mathrm{a}$ & $5.7 \mathrm{~b}$ & 72 & $<0.001$ & $<0.001$ & 0.574 \\
$\mathrm{NH}_{4}^{+}$ & 11.8 & 12.7 & 15.6 & 72 & 0.301 & $<0.001$ & 0.621 \\
$\mathrm{Nmin}^{-}$ & 20.1 & 20.7 & 21.4 & 72 & 0.948 & $<0.001$ & 0.707 \\
\hline
\end{tabular}

${ }^{[1]}$ Repeated measure analysis considering the fertiliser treatment $(\mathrm{T})$, sampling date $(\mathrm{S})$, and their interaction $(\mathrm{T} \times \mathrm{S}) .{ }^{[2]}$ Nine, eight, and ten sampling dates for the 2016, 2017, and 2018 periods, respectively.

three experimental periods. Aboveground biomass did not show effect of the treatments for the two periods of season 2016/17; however, in 2017/18 growing season, aboveground biomass in the Control treatment was $16 \%$ and $13 \%$ lower $(p<0.05)$ than in PS and PS-UI treatments, respectively. Total aboveground $\mathrm{N}$ was not affected in the three experiments by the fertiliser strategy, but grain $\mathrm{N}$ was influenced $(p=0.04)$ by the treatments when fertiliser was applied at tillering in 2017. Nitrogen use efficiency and recovery $\mathrm{N}$ efficiency did not show significant differences among treatments, independently of the season and the moment of $\mathrm{N}$ application (Table 7).

\section{Discussion}

\section{Ammonia volatilisation}

The hours that follow PS application are critical for $\mathrm{NH}_{3}$ losses. In this regard, the Directive (EU) 2016/2284 (EC, 2016) rightly suggests incorporating manures and slurries into the soil immediately or within four hours of spreading to reduce ammonia emissions from livestock manure. In this study, $2 \%$ and $7 \%$ of applied ammonium- $\mathrm{N}$ were volatilised as $\mathrm{NH}_{3}$ within the first $4.5 \mathrm{~h}$ and $6.5 \mathrm{~h}$ after the presowing and side-dress application, respectively. These values contrast with $\mathrm{NH}_{3}$ losses of $0.9 \%$ of total ammonium-N applied at presowing reported by Yagüe et al. (2019) the first $3.5 \mathrm{~h}$ after the spreading with trail-hose in a field located in the same region and under similar environmental conditions. According to the authors, soil moisture and pig slurry characteristics (dry matter) influence $\mathrm{NH}_{3}$ losses: high soil WFPS and high slurry DM boost $\mathrm{NH}_{3}$ volatilisation. These variables in conjunction with others as meteorological conditions, soil $\mathrm{pH}$, soil management, and measurement method (Hafner et al., 2018) could explain the differences between both studies.

Weather conditions determined the $\mathrm{NH}_{3}$ evolution. Ammonia volatilisation was higher during diurnal hours (first and third samplings) than at the nighttime hours (second sampling) even when exposure times at night (average 18.5 hours) were longer than diurnal exposures (average 5.5 hours). Higher temperature and wind speed during diurnal hours increased the volatilisation (Fig. $\mathrm{S} 1$ [suppl]; mean thermal amplitude of $8.2^{\circ} \mathrm{C}$ and mean wind speed amplitude of $2.3 \mathrm{~m} \mathrm{~s}^{-1}$ ). The effect of the daily pattern of air temperature and wind speed on $\mathrm{NH}_{3}$ emissions was already observed by Li et al. (2018). Similarly, differences in weather conditions between application moments might have been one of the factors responsible for higher emissions at side-dressing 2017 than at presowing 2016 since at side-dress application the temperature and wind speed were higher than at presowing.

Slurries with low DM promote the infiltration into the soil, reducing $\mathrm{NH}_{3}$ volatilisation compared to slurries with a high DM which favour crust formation and lower infiltration rates (Bosch-Serra et al., 2014). In the present study, two contrasting slurries in term of DM, $41.4 \mathrm{~kg} \mathrm{DM} \mathrm{m}^{-3}$ (presowing 2016) and $73.4 \mathrm{~kg} \mathrm{DM} \mathrm{m}^{-3}$ (side-dressing 2017), had 
Table 7. Average $(n=4)$ of productive parameters and $\mathrm{N}$ efficiency indexes in the different fertiliser treatments (Control, PS: pig slurry, PS-UI: pig slurry + MCDHS, PS-A: pig slurry + microbial activator, and PS-NI: pig slurry + DMPP). The results are presented separately by periods (presowing 2016 and side-dress 2017 and 2018). Values followed by the same letter were not significantly different ( $p>0.05$, Tukey's test).

\begin{tabular}{|c|c|c|c|c|c|c|}
\hline & Control & PS & PS-UI & PS-A & DF & $p$-value \\
\hline \multicolumn{7}{|l|}{ Presowing 2016} \\
\hline Grain $\left(\mathrm{kg} \mathrm{ha}^{-1}\right)$ & 7,237 & 6,139 & 5,695 & 6,410 & 9 & 0.083 \\
\hline Aboveground biomass $\left(\mathrm{kg} \mathrm{ha}^{-1}\right)$ & 14,454 & 13,542 & 13,549 & 14,037 & 9 & 0.719 \\
\hline Grain N (kg ha-1) & 153.9 & 122.4 & 118.8 & 134.4 & 9 & $0.048[\mathrm{a}]$ \\
\hline Total aboveground $\mathrm{N}\left(\mathrm{kg} \mathrm{ha}^{-1}\right)$ & 204.8 & 181.5 & 192.9 & 204.1 & 9 & 0.466 \\
\hline Nitrogen use efficiency & - & 1.29 & 1.37 & 1.45 & 6 & 0.525 \\
\hline Apparent $\mathrm{RE}_{\mathrm{N}}$ & - & -0.16 & -0.08 & 0.00 & 6 & 0.525 \\
\hline \multicolumn{7}{|l|}{ Side-dressing 2017} \\
\hline Grain $\left(\mathrm{kg} \mathrm{ha}^{-1}\right)$ & 6,098 & 5,591 & 5,186 & 5,123 & 9 & 0.087 \\
\hline Aboveground biomass $\left(\mathrm{kg} \mathrm{ha}^{-1}\right)$ & 13,954 & 13,831 & 13,141 & 12,760 & 9 & 0.529 \\
\hline Grain N (kg ha-1) & $129.7 \mathrm{a}$ & $119.9 \mathrm{ab}$ & $110.3 \mathrm{ab}$ & $107.2 \mathrm{~b}$ & 9 & 0.042 \\
\hline Total aboveground $\mathrm{N}\left(\mathrm{kg} \mathrm{ha}^{-1}\right)$ & 195.5 & 202.0 & 187.0 & 178.9 & 9 & 0.384 \\
\hline Nitrogen use efficiency & - & 1.19 & 1.13 & 1.31 & 6 & 0.241 \\
\hline \multirow[t]{2}{*}{ Apparent $\mathrm{RE}_{\mathrm{N}}^{[\mathrm{b}]}$} & - & 0.04 & -0.05 & -0.12 & 6 & 0.292 \\
\hline & Control & PS & PS-UI & PS-A & DF & $p$-value \\
\hline \multicolumn{7}{|l|}{ Side-dressing 2018} \\
\hline Grain $\left(\mathrm{kg} \mathrm{ha}^{-1}\right)$ & 5,938 & 6,837 & 6,471 & 6,245 & 9 & 0.393 \\
\hline Aboveground biomass ( $\left.\mathrm{kg} \mathrm{ha}^{-1}\right)$ & $14,263 \mathrm{~b}$ & $17,041 \mathrm{a}$ & $16,473 \mathrm{a}$ & $15,857 \mathrm{ab}$ & 9 & 0.007 \\
\hline Grain N $\left(\mathrm{kg} \mathrm{ha}^{-1}\right)$ & 99.2 & 122.2 & 108.3 & 107.7 & 9 & 0.245 \\
\hline Total aboveground $\mathrm{N}\left(\mathrm{kg} \mathrm{ha}^{-1}\right)$ & 153.0 & 196.3 & 168.9 & 173.3 & 9 & 0.136 \\
\hline Nitrogen use efficiency & - & 1.65 & 1.33 & 1.43 & 6 & 0.104 \\
\hline Apparent $\mathrm{RE}_{\mathrm{N}}^{[\mathrm{b}]}$ & - & 0.36 & 0.13 & 0.17 & 6 & 0.210 \\
\hline
\end{tabular}

[a] Significant effects of fertiliser treatments $(p<0.05)$ from the analysis of variance procedure, but Tukey's test did not show differences. ${ }^{[b]} \mathrm{RE}_{\mathrm{N}}-$ Recovery efficiency

to be used. This fact could have also affected the comparison of $\mathrm{NH}_{3}$ volatilisation between application moments.

Irrigation is another factor that could be relevant to compare presowing and side-dress applications. A short irrigation event of $2 \mathrm{~mm}$ was applied immediately after PS application in side-dressing 2017 to wash up the slurry placed on the canopy to avoid negative effects on leaves. This practice could have incorporated the ammonium slurry into the soil and reduced the potential for $\mathrm{NH}_{3}$ volatilisation.

Apart from the cited variables, additives could alter $\mathrm{NH}_{3}$ volatilisation. UIs are considered a strategy to reduce $\mathrm{NH}_{3}$ emissions when they are added to urea-based fertilisers or manures since they delay the transformation of urea into ammonium (Sigurdarson et al., 2018). However, the addition of UI to pig slurry is a questionable strategy because of the high probability of fast transformation of urea into ammonium after excretion (Dai \& Karring, 2014). MCDHS was evaluated in the study due to the possibility that micro-acidification, through the hydrolysis of the
MCDHS molecule, could reduce ammonia volatilisation or have potential effects over $\mathrm{N}$ dynamics (e.g., acting as $\mathrm{NI})$. Nevertheless, the presence of dihydrogen sulphate in the molecule did not reduce the $\mathrm{pH}$ of the slurry (data not shown). Moreover, no changes were observed in soil mineral $\mathrm{N}$ concentrations, ammonia losses, nitrous oxide emissions, or yield in PS-UI treatment in comparison to PS treatment, which rejects effects due to MCDHS addition.

The microbial activator, PS-A, was able to maintain higher levels of nitrate in the soil than the urease inhibitor, PS-UI, but it was not able to show differences with PS treatment. Besides, despite the higher soil $\mathrm{NO}_{3}{ }^{-}$concentration, it did not affect $\mathrm{N}_{2} \mathrm{O}$ emissions.

\section{Direct nitrous oxide emission}

Few studies have evaluated the use of NI mixed with pig slurry to mitigate $\mathrm{N}_{2} \mathrm{O}$ losses in the Mediterranean climate (Guardia et al., 2017). Under these climatic 
conditions, Recio et al. (2018) assessed the use of the nitrification inhibitor DMPP when was added to preplanting pig slurry applications (rate of $50 \mathrm{~kg} \mathrm{~N} \mathrm{ha}^{-1}$ ) on both $\mathrm{N}_{2} \mathrm{O}$ and $\mathrm{NH}_{3}$ emissions, obtaining significant abating effect on direct $\mathrm{N}_{2} \mathrm{O}$ emissions (decrease of $70 \%$ in a 22-days period after PS application) and no significant affection of cumulative $\mathrm{NH}_{3}$ emissions and Chiodini et al. (2019) found between $62 \%$ and $94 \%$ reduction in $\mathrm{N}_{2} \mathrm{O}$ emission in the crop season with emission factor being between two and four times lower when DMPP $\left(\right.$ Vizura $\left.^{\circledR}\right)$ was added to digestated and injected in the soil in a maize crop. The present work corroborates the effect of DMPP mitigating $\mathrm{N}_{2} \mathrm{O}$ emissions (decrease of 86\%) with higher abatement potential than that reported by Guardia et al. (2017) at the same slurry rate $\left(120 \mathrm{~kg} \mathrm{~N} \mathrm{ha}^{-1}\right)$ and similar to the reported by Chiodini et al. (2019) both applied to maize crop. The inhibition of the activity of nitrifiers could be noticed from the lower soil $\mathrm{NO}_{3}{ }^{-}$and higher soil $\mathrm{NH}_{4}{ }^{+}$concentrations, although significant differences were only observed for nitrate in the $0-15-\mathrm{cm}$ depth. In this regard, topsoil $\mathrm{N}$ processes are the most influential on $\mathrm{N}_{2} \mathrm{O}$ emissions since $\mathrm{N}_{2} \mathrm{O}$ produced in this layer can escape to the atmosphere (Yoh et al., 1997), whereas $\mathrm{N}_{2} \mathrm{O}$ produced at deeper layers might not reach the soil surface (Neftel et al., 2000).

In this study, avoiding $\mathrm{N}_{2} \mathrm{O}$ losses did not turn into a significant increment in $\mathrm{N}$ efficiency as could be expected: the less $\mathrm{N}_{2} \mathrm{O}$ losses, the more $\mathrm{N}$ availability, and the more $\mathrm{N}$ absorption and $\mathrm{N}$ efficiency by plants. However, this fact was unnoticed in the efficiency indicators because of the low contribution of $\mathrm{N}_{2} \mathrm{O}$ emissions to the $\mathrm{N}$ balance $\left(<1 \mathrm{~kg} \mathrm{~N}_{2} \mathrm{O}-\mathrm{N} \mathrm{ha}^{-1}\right)$ and the non-limiting soil $\mathrm{N}$ conditions proven by the high yields in unfertilised treatments during the two growing seasons.

In conclusion, important $\mathrm{N}$ losses due to ammonia volatilisation were observed after pig slurry fertilisation, lower after presowing (7-9\% of $\mathrm{NH}_{4}{ }^{+}-\mathrm{N}$ applied) than side-dressing application (19-23\% of $\mathrm{NH}_{4}{ }^{+}-\mathrm{N}$ applied) but none of the three additives evaluated in this work was effective to reduce them independently of the PS application moment, at presowing or at tillering. Nitrous oxide emissions were a minor component of the $\mathrm{N}$ balance (averaging $0.4 \%$ of $\mathrm{NH}_{4}{ }^{+}$-N applied), although its high global warming potential highlighted the importance of DMPP reducing $\mathrm{N}_{2} \mathrm{O}$ fluxes (roughly 70\%) and, accordingly, yield-scaled $\mathrm{N}_{2} \mathrm{O}$ emissions and $\mathrm{N}_{2} \mathrm{O}$ emission factors. The use of pig slurry with additives had neither advantages nor disadvantages in terms of agronomic productivity and $\mathrm{N}$ use efficiency.

\section{Acknowledgements}

Thanks to Fertinagro Biotech S.L. and BASF that provided the additives for the experiment. Thanks to the field and laboratory personnel of Unidad de Suelos y Riegos of CITA.

\section{References}

Abalos D, Jeffery S, Sanz-Cobena A, Guardia G, Vallejo A, 2014. Meta-analysis of the effect of urease and nitrification inhibitors on crop productivity and nitrogen use efficiency. Agric Ecosyst Environ 189: 136-144. https://doi.org/10.1016/j.agee.2014.03.036

Aguilera E, Lassaletta L, Sanz-Cobena A, Garnier J, Vallejo A, 2013. The potential of organic fertilizers and water management to reduce $\mathrm{N}_{2} \mathrm{O}$ emissions in Mediterranean climate cropping systems. A review. Agric Ecosyst Environ 164: 32-52. https://doi.org/10.1016/j. agee.2012.09.006

Allen RG, Pereira LS, Raes D, Smith M, 1998. Crop evapotranspiration: guidelines for computing crop water requirements. FAO Irrig Drain Paper 56, Rome (Italy).

Alves BJR, Smith KA, Flores RA, Cardoso AS, Oliveira WRD, Jantalia CP, Urquiaga S, Boddey RM, 2012. Selection of the most suitable sampling time for static chambers for the estimation of daily mean $\mathrm{N}_{2} \mathrm{O}$ flux from soils. Soil Biol Biochem 46: 129-135. https://doi. org/10.1016/j.soilbio.2011.11.022

Araújo ESE da S, Marsola T, Miyazawa M, Soares LH de B, Urquiaga S, Boddey RM, Alves, BJR, 2009. Calibração de câmara semiaberta estática para quantificação de amônia volatilizada do solo. Pesqu Agropec Bras 44: 769-776. https://doi.org/10.1590/S0100204X2009000700018

Bosch-Serra AD, Yagüe MR, Teira-Esmatges MR, 2014. Ammonia emissions from different fertilizing strategies in Mediterranean rainfed winter cereals. Atmos Environ 84: 204-212. https://doi.org/10.1016/j.atmosenv.2013.11.044

Chiodini E, Perego A, Carozzi M, Acutis M, 2019. The nitrification inhibitor Vizura ${ }^{\circledR}$ reduces $\mathrm{N}_{2} \mathrm{O}$ emissions when added to digestate before injection under irrigated maize in the Po Valley (Northern Italy). Agronomy 9: 431. https://doi.org/10.3390/agronomy9080431

Dai X, Karring H, 2014. A determination and comparison of urease activity in feces and fresh manure from pig and cattle in relation to ammonia production and $\mathrm{pH}$ changes. PLOS ONE 9: e110402. https://doi. org/10.1371/journal.pone.0110402

EEA, 2016. European Union emission inventory report 1990-2013 under the UNECE Convention on Long-range Transboundary Air Pollution (LRTAP). European Environment Agency. https://doi. org $/ 10.2800 / 18374$

EEA, 2019a. Air quality in Europe - 2019 report. European Environment Agency. https://doi.org/10.2800/822355

EEA, 2019b. European Union emission inventory report 1990-2017 under the UNECE Convention on Long-range Transboundary Air Pollution (LRTAP). European Environment Agency. https://doi. org $/ 10.2800 / 78220$ 
EEA, 2019c. EMEP/EEA air pollutant emission inventory guidebook 2019. European Environment Agency. https://doi.org/10.2800/293657

EC, 2016. Council Directive 2016/2284/EC on the reduction of national emissions of certain atmospheric pollutants, amending Directive 2003/35/EC and repealing Directive 2001/81/EC. 14 December 2016 [LEX-FAOC161484].

Fangueiro D, Hjorth M, Gioelli F, 2015. Acidification of animal slurry- A review. J Environ Manage 149: 4656. https://doi.org/10.1016/j.jenvman.2014.10.001

FAO, 2020. FAOSTAT database collections. FAO, Rome (Italy). http://www.fao.org/faostat/en/\#data [3.Jun.20).

Guardia G, Cangani MT, Sanz-Cobena A, Junior JL, Vallejo A, 2017. Management of pig manure to mitigate $\mathrm{NO}$ and yield-scaled $\mathrm{N}_{2} \mathrm{O}$ emissions in an irrigated Mediterranean crop. Agric Ecosyst Environ 238: 55-66. https://doi.org/10.1016/j.agee.2016.09.022

Guevara M, Tena C, Porquet M, Jorba O, Pérez García-Pando C, 2019. HERMESv3, a stand-alone multiscale atmospheric emission modelling framework Part 2: bottom-up module. Geosci Model Dev Discuss 1-51. https://doi.org/10.5194/gmd-2019-295

Hafner SD, Pacholski A, Bittman S, Burchill W, Bussink W, Chantigny M, et al., 2018. The ALFAM2 database on ammonia emission from field-applied manure: Description and illustrative analysis. Agric For Meteorol 258: 66-79. https://doi.org/10.1016/j.agrformet.2017.11.027

Hristov AN, 2011. Technical note: Contribution of ammonia emitted from livestock to atmospheric fine particulate matter $\left(\mathrm{PM}_{2.5}\right)$ in the United States. J Dairy Sci 94: 3130-3136. https://doi.org/10.3168/jds.2010-3681

IPCC, 2019. $\mathrm{N}_{2} \mathrm{O}$ emissions from managed soils, and $\mathrm{CO} 2$ emissions from lime and urea application. In: 2019 Refinement to the 2006 IPCC Guidelines for National Greenhouse Gas Inventories, Vol 4, Chapt 11. Intergovernmental Panel on Climate Change, Geneva, Switzerland. 48 pp.

Li M, Wang Y, Adeli A, Yan H, 2018. Effects of application methods and urea rates on ammonia volatilization, yields and fine root biomass of alfalfa. F Crop Res 218: 115-125. https://doi.org/10.1016/j.fcr.2018.01.011

MacKenzie AF, Fan MX, Cadrin F, 1998. Nitrous oxide emission in three years as affected by tillage, corn-soybean-alfalfa rotations, and nitrogen fertilization. J Environ Qual 27: 698-703. https://doi.org/10.2134/ jeq1998.00472425002700030029x

MAPA, 2020. Encuestas ganaderas. Análisis del número de animales por tipos: Resultados de porcino. Ministerio de Agricultura Pesca y Alimentación, Spain. https://www. mapa.gob.es/es/estadistica/temas/estadisticas-agrarias/ ganaderia/encuestas-ganaderas/ [3.Jun.20].

Mateo-Marín N, Quílez D, Guillén M, Isla R, 2020. Feasibility of stabilised nitrogen fertilisers decreasing greenhouse gas emissions under optimal management in sprinkler irrigated conditions. Agric Ecosyst Environ 290: 106725. https://doi.org/10.1016/j. agee.2019.106725

Myhre G, Shindell D, Bréon FM, Collins W, Fuglestvedt J, Huang J, et al., 2013. Anthropogenic and natural radiative forcing. In: Climate Change 2013 - The Physical Science Basis; Intergovernmental Panel on Climate Change (Ed.). Cambridge Univ Press, UK, pp: 659-740.

Neftel A, Blatter A, Schmid M, Lehmann B, Tarakanov $\mathrm{SV}, 2000$. An experimental determination of the scale length of $\mathrm{N}_{2} \mathrm{O}$ in the soil of a grassland. J Geophys Res Atmos 105: 12095-12103. https://doi.org/10.1029/ 2000JD900088

Recio J, Vallejo A, Le-Noë J, Garnier J, García-Marco S, Álvarez JM, Sanz-Cobena A, 2018. The effect of nitrification inhibitors on $\mathrm{NH}_{3}$ and $\mathrm{N}_{2} \mathrm{O}$ emissions in highly $\mathrm{N}$ fertilized irrigated Mediterranean cropping systems. Sci Total Environ 636: 427-436. https://doi. org/10.1016/j.scitotenv.2018.04.294

Sanz-Cobena A, Lassaletta L, Aguilera E, del Prado A, Garnier J, Billen G, et al., 2017. Strategies for greenhouse gas emissions mitigation in Mediterranean agriculture: A review. Agric Ecosyst Environ 238: 5-24. https://doi.org/10.1016/j.agee.2016.12.032

Sigurdarson JJ, Svane S, Karring H, 2018. The molecular processes of urea hydrolysis in relation to ammonia emissions from agriculture. Rev Environ Sci Bio/Technology 17: 241-258. https://doi.org/10.1007/s11157-018-9466-1

Soil Survey Staff, 2014. Keys to Soil Taxonomy, 12th ed. USDA Natural Resources Conservation Service, Washington DC, USA.

Ti C, Xia L, Chang SX, Yan X, 2019. Potential for mitigating global agricultural ammonia emission: A meta-analysis. Environ Pollut 245: 141-148. https://doi. org/10.1016/j.envpol.2018.10.124

UNEP, 2013. Drawing down $\mathrm{N}_{2} \mathrm{O}$ to protect climate and the ozone layer. A UNEP Synthesis Report. United Nations Environment Programme, Nairobi, Kenya.

Ussiri D, Lal R, 2013. Soil emission of nitrous oxide and its mitigation. Springer Netherlands, Dordrecht. DOI:10.1007/978-94-007-5364-8 https://doi. org/10.1007/978-94-007-5364-8

Vitousek PM, Aber J, Howarth RW, Likens GE, Matson PA, Schindler DW, Schlesinger WH, Tilman GD, 1997. Human alteration of the global nitrogen cycle: causes and consequences issues in ecology. Issues Ecol 1: 1-17.

Yagüe MR, Quílez D, 2012. On-farm measurement of electrical conductivity for the estimation of ammonium nitrogen concentration in pig slurry. J Environ Qual 41: 893-900. https://doi.org/10.2134/jeq2011.0352

Yagüe MR, Valdez AS, Bosch-Serra ÀD, Ortiz C, Castellví F, 2019. A short-term study to compare field 
strategies for ammonia emission mitigation. J Environ Qual 48: 179-184. https://doi.org/10.2134/jeq2018.05. 0218

Yoh M, Toda H, Kanda K, Tsuruta H, 1997. Diffusion analysis of $\mathrm{N}_{2} \mathrm{O}$ cycling in a fertilized soil. Nutr Cycl Agroecosyst 49: 29-33. https://doi.org/10.1023/A:1009757829417

Zerulla W, Barth T, Dressel J, Erhardt K, Horchler von Locquenghien K, Pasda G, et al., 2001a. 3,4-Dimethyl- pyrazole phosphate (DMPP) - A new nitrification inhibitor for agriculture and horticulture. Biol Fertil Soils 34: 79-84. https://doi.org/10.1007/s003740100380

Zerulla W, Pasda G, Hähndel R, Wissemeier AH, 2001b. The new nitrification inhibitor DMPP $\left(\right.$ ENTEC $\left.^{\circledR}\right)$ for use in agricultural and horticultural crops - An overview. In: Plant Nutrition. Springer Netherlands, Dordrecht, pp: 754-755. https://doi.org/10.1007/0-30647624-X_366 